\title{
Processos de criação teatral em comunidades e sua relação com o bairro - Tecendo um teatro ecoafetivo por meio da experiência do Coletivo Pipa Azul no Bairro Serviluz
}

\section{RESUMO}

O texto aqui referido visa a relatar a experiência do "Coletivo Pipa Azul” - grupo fortalezense que almejava pesquisar, por meio do teatro, as relações sociais e ambientais tecidas no bairro Serviluz, considerando o contato, as percepções e as sensações dos integrantes do Coletivo (em sua grande maioria crianças e adolescentes) no processo de formação da obra “"Saco” ou "Plástico"”, propondo pistas cartográficas para o entendimento da obra e da sua relação com o bairro e com os integrantes que compõem o coletivo.

PALAVRAS-CHAVE: Cartografia; processo; coletivo artístico; teatro ecoafetivo; relato de experiência

\begin{abstract}
This text refers to the experience of the "Coletivo Pipa Azul" - a group held in the city of Fortaleza that sought to research, through theather, the social and environmental relations woven in the Serviluz neighborhood, considering the contact, the perceptions and the sensations of the members of the Collective (who are mainly children and adolescents) in the development process of the work "'Saco" ou "Plastico"'”, proposing cartographic tracks for the understanding of this work and its relationship with the neighborhood and with the members that compose the collective.
\end{abstract}

KEY WORDS: Cartography; process; artistic collective; ecoaffective theater; experience report.

O Coletivo Pipa Azul é um grupo que teve como cerne a pesquisa em teatro e educação ecoafetiva/socioambiental, trilhado de agosto de 2014 a agosto de 2016 no bairro Serviluz, na cidade de Fortaleza/CE, em contato profundo com o Programa de extensão "Programa Verdeluz de Sustentabilidade” da Universidade Federal do Ceará (UFC). Mais de oitenta participantes passaram pelo Coletivo, tendo uma média de 15 participantes fixos, em sua maioria de quatro a quinze anos, mulheres e negras. Os encontros aconteciam semanalmente, aos sábados e 
domingos, das 9h30 às 11h30. O bairro Serviluz - lar para as ações e pesquisa do coletivo localiza-se em uma região de vulnerabilidade socioeconômica e ambiental. O grupo teve como abrigos a Associação Boca do Golfinho - centro comunitário de Esporte, Cultura, Cidadania e Lazer - e a faixa praiana em frente à associação.

Em 2015, um dos processos que se perfizeram dentro da trajetória do Coletivo foi o desenvolvimento da obra “"Saco” ou "Plástico"”, que abordou - a partir da ação cênica dos atores e de uma experimentação visual que acompanhava todos os 20 minutos de performance - três temáticas principais: a poluição urbana das ruas do Serviluz, grande vetor de doenças de pele, sobretudo para crianças e adolescentes do bairro; a poluição marinha, visto que parte do plástico descartado de maneira indevida nas praias do Serviluz afeta negativamente a fauna marinha (isso foi estudado pelos integrantes do Coletivo a partir de sua vivência no surfe e do contato com o GTAR - grupo de estudos sobre tartarugas e outros animais marinhos atuante em Fortaleza/CE); e a proposição do funk enquanto possibilidade artística, salientando que a utilização desse ritmo nos laboratórios do Pipa Azul sempre gerou controvérsias entre os pais e responsáveis dos participantes. Nesse último ponto, cabe frisar que a obra “"Saco” ou "Plástico”” é acompanhada em diversos momentos de músicas do Funclassic - grupo paulista que visa a explorar a mistura entre música erudita e as musicalidades produzidas no cenário dos baile funks da cidade de São Paulo - propondo uma fricção ainda maior a respeito do tema, evocando, assim, o funk para dentro do fazer cênico e teatral do Coletivo, tudo isso sendo sempre discutido e debatido com as crianças e adolescentes integrantes, potencializando assim o caráter formativo que essas ações podem tomar.

Para analisar referidas trocas laboratoriais, esta investigação propõe-se à cartografia, conforme o sugerido por Rolnik. Utiliza-se esta autora como referencial em virtude do potencial da cartografia no que diz respeito a paisagens psicossociais, dado que a cartografia é "um desenho que acompanha e se faz ao mesmo tempo de transformação da paisagem" (ROLNIK, 2006, p. 48). Nesse sentido, mundos desmoronam enquanto formam-se outros; estes, a seu turno, pautados por afetos contemporâneos. Dessa maneira, entendemos que a trajetória trazida pelos integrantes - tendo sido eles os instigadores das três temáticas propostas - a partir de seu contato com o bairro é salutar para a composição da obra, bem como o contato da cena com as(os) moradoras(es) da região, gerando, a partir disso, novas composições, novos olhares e novas camadas à própria obra 
artística (ROLNIK, 1997). “Saco” foi apresentada em quatro espaços diferentes no estado do Ceará, em um total de doze apresentações, sendo a maioria delas feita no Serviluz. Essas ações no próprio bairro foram de gigante importância para propor possíveis diálogos em direção às questões propostas na cena, sendo ela incitadora de possíveis debates e ações sociais a respeito das temáticas referidas. O fazer cênico, dessa forma, agencia-se enquanto um canal de diálogo com e para a sociedade - reinventando a si mesmo nesse processo, assumindo novas facetas, novas urgências e novas ações para dentro da criação teatral-performativa.

\section{REFERÊNCIAS BIBLIOGRÁFICAS}

ARTAUD, Antonin. O Teatro e seu Duplo. São Paulo. Martins Editora, 2006.

ROLNIK, S., Instauraçoes de mundos. Sao Paulo, Domínio Virtual, http://www.pucsp.br/nucleodesubjetividade/Textos/SUELY/Instauracao.pdf, 1997

, Cartografia sentimental: transformações contemporâneas do desejo. Porto Alegre: Sulina; Editora da UFRGS, 2006. 